\title{
O amor em Marília de Dirceu, de Tomás Antônio Gonzaga
}

\author{
The love in 'Marilia de Dirceu', by Tomás Antônio Gonzaga
}

Gracinéa Imaculada Oliveira*

Faculdade de Letras da Universidade Federal de Minas Gerais

Belo Horizonte, Minas Gerais, Brasil

Eliane Beatriz Carneiro Leal ${ }^{* *}$

Faculdade de Letras da Universidade Federal de Minas Gerais

Belo Horizonte, Minas Gerais, Brasil

Leilimara Rosenda de Jesus ${ }^{* * *}$

Faculdade de Letras da Universidade Federal de Minas Gerais

Belo Horizonte, Minas Gerais, Brasil

Matheus Paul da Silva Cruz ${ }^{* * * *}$

Faculdade de Letras da Universidade Federal de Minas Gerais

Belo Horizonte, Minas Gerais, Brasil

\begin{abstract}
Resumo: O objetivo deste artigo é apresentar os resultados de uma pesquisa relativa ao livro Marília de Dirceu, de Tomás Antônio Gonzaga. Nesse trabalho, analisaram-se as imagens do amor na primeira e na segunda partes dessa obra. Foi uma pesquisa de cunho bibliográfico, em que a partir de revisão de bibliografia publicada sobre o livro e dos conceitos de amor presentes em O Banquete, de Platão, verificou-se como o amor está representado nas liras dedicadas a Marília. Para isso, partiu-se do pressuposto de que o amor que é representado nas liras pode ser relacionado aos discursos a respeito do amor presentes em O Banquete. Após a análise, constatou-se que o amor nas duas primeiras partes de Marília de Dircen é o amor platônico, sintetizado no discurso de Sócrates.
\end{abstract}

Palavras-chave: Amor. Marilia de Dirceu. Banquete. Platão. Poesia.

Abstract: This article presents the results from a study of the book, Marilia de Dircen, by Tomás Antônio Gonzaga, which analyzed the images of love in the first and second parts of this work. This study followed the molds of a bibliographic research which, through a review of the bibliography published about the book itself and the concepts of love presented in The Banquet, by Plato, verified how love is represented in the lyrics dedicated to Marilia. To achieve this, this study was based on the presumption that the love represented in the lyrics can be linked to the discourses referent to love present in the The Banquet. After this analysis, it was determined that love in the two first parts of Marilia de Dirceu is plutonic love, synthesized within the discourse formulated by Socrates.

Keyswords: Love. Marília de Dirceu. The Banquet. Plato. Poetry.

* Doutora em Literatura Brasileira pela Faculdade de Letras da Universidade Federal de Minas Gerais. Professora da Faculdade de Ciências Sociais Aplicadas de Belo Horizonte - FACISABH, Belo Horizonte, MG, Brasil. E-mail: gracineaoliveira@hotmail.com.

** Graduada em Letras pela Faculdade de Ciências Sociais Aplicadas de Belo Horizonte - FACISABH, Belo Horizonte, MG, Brasil. E-mail: elianebeatriz31@hotmail.com.

*** Graduada em Letras pela Faculdade de Ciências Sociais Aplicadas de Belo Horizonte - FACISABH, Belo Horizonte, MG, Brasil. E-mail: leilimararosenda@gmail.com.

**** Graduado em Letras - Língua Portuguesa e suas Literaturas - pela FACISABH. Professor de Língua Portuguesa do Ensino Básico. E-mail: matheuspaul2@gmail.com. 


\section{INTRODUÇÃO}

O objeto de análise deste artigo é o livro Marília de Dirceu, de Tomás Antônio Gonzaga, poeta cuja obra faz parte do Neoclassicismo ou arcadismo. As composições presentes no livro seguem o padrão neoclássico e são influenciadas pela literatura grecorromana. $O$ tema mais recorrente e que chamou mais a atenção foi o amor.

Em relação ao autor, consta que

[...] nasceu [no][P]orto, 1744 [e morreu em] Moçambique, 1810[.] [F]ormou-se em direito, em Coimbra, em 1768, e veio para o Brasil em 1782. Exerceu o cargo de ouvidor em Vila Rica, onde noivou com D. Maria Dorotéia Joaquina de Seixas, a Marília de suas liras. Envolvido na inconfidência, os desentendimentos que tinha com o governador Cunha de Meneses foram sua perdição. Condenado ao degredo vai para Moçambique, onde reconstrói sua vida, esquecendo completamente a poesia. A última palavra sobre a biografia de Gonzaga está nos estudos recentes de M. Rodrigues Lapa. (COUTINHO, 2004, p. 227).

Marilia de Dirceu é composto, em sua maior parte, de liras. Ele é dividido em três partes, sendo que foram analisadas as duas primeiras. O motivo da exclusão da terceira parte deu-se por não ser composta apenas por liras e, também, pelo fato de os poemas dessa seção tratarem de diferentes temáticas. Além disso, esses poemas não tem apenas uma única musa poética. Em relação às duas primeiras partes do livro, a principal diferença entre elas é a situação de Dirceu: na primeira se apresenta livre e, na segunda, apresenta-se preso em uma masmorra.

Os poemas têm elementos típicos da poesia árcade, tal como paisagem bucólica, pastores e intertextualidade com a mitologia grecorromana. As duas primeiras partes de Marília de Dircen apresentam também as seguintes características:

[...] simplicidade, mas nobreza, na linguagem; imitação da natureza, aformoseando-a, ou como diríamos hoje, estilizando-a; procura de motivos bucólicos, simples, utilizando-se os poetas de vocabulário e situação mais ou menos comuns, figurando-se um pastor residindo numa choça, tratando do seu gado, etc. (COUTINHO, 2004, p. 222).

Tais aspectos estão presentes, por exemplo, na lira I da primeira parte, em que Dirceu se diz pastor dono de um farto gado e de ovelhas. Também faz referência à vida do campo, alegando ser essa vida confortável em meio à simplicidade da natureza. Nessa primeira lira, também é possível perceber alguns valores burgueses vigentes naquela época, na qual os grandes fazendeiros retinham grande parte dos meios de produção e a exploração do ouro gerava riquezas. O eu lírico demonstra para sua musa quanto poder ele possuía para, assim, chamar sua atenção. Em síntese, nessa lira, o pastor Dirceu é um homem de muitas posses.

Eu, Marília, não sou algum vaqueiro,

Que viva de guardar alheio gado,

De tosco trato de expressões grosseiro,

Dos frios gelos e do sóis queimado.

Tenho próprio casal e nele assisto;

Das brancas ovelhinhas tiro o leite,

$\mathrm{E}$ mais as finas lãs, de que me visto.

Graças, Marília bela,

Graças à minha estrela! 
Eu vi o meu semblante numa fonte,

Dos anos inda não está cortado:

Os pastores, que habitam este monte,

Com tal destreza toco a sanfoninha,

Que inveja até me tem o próprio Alceste:

Ao som dela concerto a voz celeste;

Nem canto letra, que não seja minha,

Graças, Marília bela,

Graças à minha Estrela! (GONZAGA, 2015, p. 7).

Como é possível perceber, nesse poema estão presentes elementos pastoris como pastor, pastora e demais aspectos da poesia árcade e bucólica. Mas, além de tais fatos, o que mais sobressai nessa obra, como já afirmado anteriormente, é o amor. Por isso, foi esse o tema escolhido para ser analisado neste artigo. Sendo assim, buscou-se, nesta pesquisa, responder à seguinte pergunta: Como o amor é representado nas duas primeiras partes do livro Marília de Dirceu?

Para responder a essa questão, analisaram-se as imagens do amor presentes nesse livro, relacionando-as com os discusos contidos em O Banquete de Platão. Supôs-se que se encontrariam pontos em comum entre os discursos de Fedro, Pausânias, Erixímaco, Aristófanes, Agatão, Sócrates e o amor nas liras de Gonzaga.

A escolha do tema, do objeto e do problema foi norteada pela relevância dessa obra para a literatura brasileira, como demonstrou Oliveira (2001, p. 97-105) em pesquisa realizada sobre a recepção desse livro nos séculos XIX e XX. Além disso, considera-se, também, ser importante para a área de Letras a análise dessa temática, já que se trata de um tema universal e atemporal.

\section{REFERENCIAL TEÓRICO-METODOLÓGICO}

\subsection{Percurso metodológico}

Esta pesquisa é de cunho bibliográfico, por ter sido "[...] desenvolvida com base em material já elaborado, constituído principalmente de livros e artigos científicos". (GIL, 2009, p. 44). Além de bibliográfica, esta pesquisa é também qualitativa, entendida por Gil (2009, p. 48) como a pesquisa que considera que há uma relação dinâmica entre o mundo real e o sujeito, isto é, um vínculo indissociável entre o mundo objetivo e a subjetividade. Essa característica não pode ser traduzida em números, por isso sua escolha para esta análise, em que o processo e seu significado foram os focos principais de abordagem. Para a seleção das liras usadas neste artigo, foi feita uma coleta de dados da primeira e da segunda parte do livro objeto de pesquisa para facilitar o cotejo com os discursos de $O$ Banquete. Em seguida, foi feita a análise. É importante registrar que foram analisadas todas as liras que tinham como tema o amor ou que tangenciavam essa temática.

\subsection{Revisão de bibliografia}

Tomás Antônio Gonzaga é um poeta que sempre teve sua vida relacionada à sua obra poética pela maior parte da crítica. Devido a seu noivado com Maria Dorotéa, as liras da primeira e da segunda parte parecem ser dedicadas a ela: "E este invólucro brilhante e sereno daria dignidade e valor coletivo à nota da experiência pessoal." (CANDIDO, 2010, p. 118). Porém, como crítico metódico e experiente que é, Candido questiona como se dá a relação entre a realidade e a ficção nessa obra de Gonzaga: 


\section{das Letras}

O problema consiste em avaliar até que ponto a Marília de Dircen é um poema de lirismo amoroso tecido a volta duma experiência concreta - a paixão, o noivado, a separação de Dirceu (Gonzaga) e Marília (Maria Dorotéia Joaquina de Seixas) - ou roteiro de uma personalidade, que se analisa e expõe, a pretexto da referida experiência. (CANDIDO, 2010, p. 118).

Sendo assim, percebe-se que essa relação entre vida e obra é muito complexa, como também demonstra Coutinho (2004), ao afirmar que

O poeta era um pintor de situações, não de emoções. [...] sentimentos e emoções não deviam ser referidos diretamente, mas subtendidos do jogo das comparações e da analogia com incidentes mitológicos (COUTINHO, 2004, v. II, p. 229).

Como se vê, em Marília de Dircen o que sobressai é o artifício poético, não uma confissão da vida pessoal do poeta. Esse jogo é perceptível na lira XXX da parte I:

Junto a uma clara fonte

A mãe de amor se sentou;

Encostou na mão o rosto,

No leve sono pegou.

Cupido, que a viu de longe,

Contente ao lugar correu;

Cuidando que era Marília,

$\mathrm{Na}$ face um beijo lhe deu.

Acorda Vênus irada:

Amor a conhece; e então

Da ousadia, que teve,

Assim lhe pede o perdão:

Foi fácil, ó mãe formosa,

Foi fácil engano meu;

Que o semblante de Marília

É todo semblante teu (GONZAGA, 2015, p. 70 - 71).

Como é perceptível no poema transcrito, o engano de Cupido serve apenas para demonstrar que Marília era tão bela quanto Vênus, a ponto de seduzir o próprio Amor. Percebese, então, que, nessa lira especificamente, o que está em relevo é a situação, não a emoção. Mas essa situação serviu não apenas para representar uma mulher, que nesse caso poderia ser Maria Dorotéa, mas, sim, para criar um mito que se tornou referência na literatura brasileira:

Dorotéia se desindividualizou para ser absorvida na convenção arcádica: é a pastora Marília, objeto ideal de poesia, sem existência concreta. Por isso mesmo, ora é loura, ora morena; ora compassiva, ora cruel: em qualquer caso, sem nervo nem sangue é uma estatueta de porcelana que o poeta envolve na revoada de cupidos, rosas e abelhas. (CANDIDO, 2010, p. 121).

Mas esses artifícios poéticos estão presentes na poesia lírica de Gonzaga não apenas em relação a situações ou à figura feminina, mas também em relação ao amor, como demonstrou 
Almeida (2006) em pesquisa relativa à obra desse poeta. O objetivo de seu artigo foi verificar como Gonzaga trabalha o amor nesse livro, levando em consideração a imagem que o poeta constrói de si mesmo e a imagem que ele constrói da amada. O tema da obra, marcada por características pré-românticas, sem sombra de dúvidas é o amor: o homem em sua busca pela mulher amada. Almeida (2006, p.188) afirma que, além do amor, o erotismo também aflora nessa poesia: "[...] um certo gosto a erotismo que percorre o conjunto das poesias, como já tem sido evidenciado por vários críticos. O amante Dirceu introduz no discurso uma pitada de sensualidade, por via do apelo ao desfrute do momento presente”. Por diversas vezes, o eu lírico recorre ao discurso amoroso para construir essa sensualidade implícita, através do jogo encenado por Dirceu a Marília.

Mas o que Almeida (2006, p. 216-219) mais analisa em seu artigo é o movimento do sujeito lírico: de uma hipertrofia da imagem que o poeta constrói de si na primeira parte das liras para uma subalternização desse sujeito na segunda parte:

Dirceu é um ser entre duas formas de realizações possíveis, divididas entre paradigmas de amor antagónicos, não conseguindo ocultar totalmente o sentimento de 'servo do amor' (da amada) por sobre a espessa camada de verniz, a harmonizar a expressão poética com a atitude amorosa expectável de parte do homem mais velho [...], mas sempre superior face à pueril e inexperta Marília bela (ALMEIDA, 2006, p. 218-219).

$\mathrm{Na}$ verdade, a hipertrofia é apenas uma máscara desse sujeito, ou melhor, para Almeida (2006, p. 220), é a condição do autêntico apaixonado, "aquele que (re)conhece, na sua intimidade, que o outro está submetido a um habitat superior, um Olimpo onde tudo se decide [...]". O que se percebe, a partir da leitura da obra e de alguns estudos críticos, como o de Almeida, é que o amor em Marília de Dirceu é encenado por um pastor para quem a amada está em um nível superior, habitado pelos deuses.

\section{RESULTADOS}

Mas o amor e o interesse por esse tema não é construção do século XVIII, é antigo na literatura e na filosofia: vem desde a época Clássica. Em O Banquete (1972), esse é o tema principal do jantar, preparado para homenagear Agatão, que havia ganhado um prêmio. É feito um acordo entre os presentes antes do jantar, para que não ficassem embriagados e que, da esquerda para direita, fizessem discursos de louvor ao amor.

Com efeito, aparecem na narrativa discursos indiretos e diretos, formando vários diálogos. Ocorrem no livro seis discursos sobre o amor, sendo todos necessários para entender esse conceito: são os discursos de Fedro, Pausânias, Aristófanes, Agatão, Erixímaco e Sócrates. É notável a ênfase em Sócrates, sua participação é importante para o desfecho dos discursos. Embora haja divergência entre eles, no fim, Sócrates parece ter razão.

O primeiro foi feito por Fedro. Seu discurso vai do parágrafo 178a até o 180b. Nesse discurso, Fedro afirma que o amor é um grande Deus e o mais antigo. Para ele, a maior capacidade do amor é tornar virtuoso aquele que ama. O apaixonado busca fazer coisas boas e belas, para chamar a atenção da amada, tornando o amor o bem mais precioso ao homem. No entanto não são as riquezas materiais que oferecem aos homens a virtude e a honra, isto é dado pelo amor. Portanto, como afirma Fedro, quem está disposto a viver bem, deve estar sempre em busca do amor. 


\section{das Letras}

E sendo o mais antigo [o Amor] é para nós a causa dos maiores bens. Não sei eu, com efeito, dizer que haja maior bem para quem entra na mocidade do que um bom amante, e para um amante, do que o seu bem-amado. Aquilo que, com efeito, deve dirigir toda a vida dos homens, dos que estão prontos a vivê-la nobremente, eis o que nem a estirpe pode incutir tão bem, nem as honras, nem a riqueza, nem nada mais, como o amor. (PLATÃO, O banquete, 180b).

Na lira XIX da II parte, Dirceu afirma ser sua dor amenizada pelo amor sentido por Marília. $\mathrm{O}$ amor causou ao amante resistência a momentos de sofrimento:

$[\ldots]$

Nesta triste masmorra,

De um semivivo corpo sepultura, Inda, Marília, adoro

A tua formosura.

Amor na minha ideia te retrata;

Busca, extremoso, que eu assim resista

A dor imensa, que me cerca e mata. (GONZAGA, 2015, p. 114).

Como se vê, assim como para Fedro, para Dirceu, mesmo em uma situação extremamente degradante, o amor é um bem que lhe permite resistir àquele sofrimento.

O segundo discurso é feito por Pausânia. Ele divide o amor em Urânio, o Celestial; e Pandêmio, o popular. $\mathrm{O}$ amor Celestial está presente quando os amantes

Estão dispostos, penso eu, os que começam desse ponto, amar para acompanhar toda vida e viver em comum, e não enganar e, depois de tomar o jovem em sua inocência e ludibriálo, a partir da procura de outro. (PLATÃO, O banquete,181 d).

$\mathrm{Na}$ lira XV da parte II, o amor pode ser relacionado a esse tipo de amor:

Nós iremos pescar na quente sesta

Com canas e com cestos os peixinhos;

Nós iremos caçar nas manhãs frias

Com a vara envisgada os passarinhos.

Para nos divertir faremos quanto

Reputa o varão sábio, honesto e santo.

Nas noites de serão nos sentaremos

C' os filhos, se os tivermos, à fogueira;

Entre as falsas histórias, que contares,

Lhes contarás a minha, verdadeira:

Pasmados te ouvirão; eu, entretanto

Ainda o rosto banharei de pranto.

Quando passarmos juntos pela rua,

Nos mostrarão c'o dedo os mais pastores,

Dizendo uns para os outros: Olha nossos

Exemplos da desgraça, e são amores.

Contentes viveremos dessa sorte,

Até que um dos dois chegue à morte (GONZAGA, 2015, p. 108). 
Nessa lira, Dirceu faz planos para o futuro com Marília. Assim como no amor Urânio, há aqui o desejo de partilha de uma vida, vida essa bucólica e simples, bonita e amorosa como a natureza. Em uma paisagem idílica, a ênfase é em dois seres unidos pelo amor e pelo desejo de partilhar juntos a vida e de serem exemplos para os demais. Pelo menos é essa a ideia que Dirceu quer passar para Marília, já que nessa lira há apenas a voz do eu lírico, a desenhar esse futuro idílico ele e para a amada.

O amor de Dirceu é, na maior parte dos poemas, como o amor que queria louvar Pausânias (Urânio), pois em várias liras é possível notar que o eu lírico deseja passar a vida toda ao lado de sua amada, como na Lira IX, em que se declara grande amante de Marília e compara o amor a uma prisão, na qual ele foi preso não por violência, mas pelo amor que sente por sua musa poética.

Eu sou, gentil Marília, eu sou cativo;

Porém não me venceu a mão armada

De ferro e de furor:

Uma alma sobre todas elevada

Não cede a outra força que não seja

À tenra mão do amor.

Arrastem pois os outros muito embora

Cadeias nas bigornas trabalhadas

Com pesados martelos:

Eu tenho as minhas mãos ao carro atadas

Com duros ferros não, com fios d'ouro,

Que são seus cabelos. (GONZAGA, 2015, p. 25).

Porém, no discurso de Pausânias há a descrição de outro tipo de amor, que seria o amor Pandêmio, o qual não se conseguiu atribuir a Dirceu.

E amam tais pessoas, primeiramente não menos que as mulheres que os jovens, e depois o que neles amam é mais o corpo que a alma, e ainda dos mais desprovidos de inteligência, tendo em mira apenas o efetuar o ato, sem se preocupar se é decentemente ou não; daí resulta então que eles fazem o que lhes ocorre, tanto o que é bom como o seu contrário. (PLATÃO, O banquete, $181 \mathrm{~b})$.

O terceiro discurso é feito por Aristófanes, que defende sua ideia a partir da origem da humanidade. Para ele, no princípio, não havia apenas homem e mulher, existia também um terceiro gênero chamado Andrógino. Os andróginos foram divididos em dois e depois disso estão sempre à procura de sua metade:

Em primeiro lugar, três eram os gêneros da humanidade, não dois como agora, masculino e o feminino, mas também havia a mais um terceiro, comum a estes dois, do qual resta agora um nome, desaparecida a coisa; andrógino era então um gênero distinto, tanto na forma como no nome comum aos dois, ao masculino e ao feminino, enquanto agora nada mais é que um nome posto em desonra. (PLATÃO, O banquete, 189d-e)

Por conseguinte, desde que a nossa natureza se mutilou em duas, ansiava cada um por sua própria metade e a ela se unia, envolvendo-se com as mãos e enlaçando-se um ao outro, no ardor de se confundirem, morriam de fome e de inércia em geral, por nada quererem fazer longe um do outro. (PLATÃO, O banquete, 191a-b). 


\section{das Letras}

$\mathrm{Na}$ lira $\mathrm{V}$ da parte I, Dirceu é dependente de Marília, tal como os andróginos também eram um do outro após a separação. Há uma conexão entre as partes separadas. Com efeito, a felicidade de Dirceu dependia de sua amada, pois a falta dela o deixava triste. O contentamento do andrógino também dependia de sua metade.

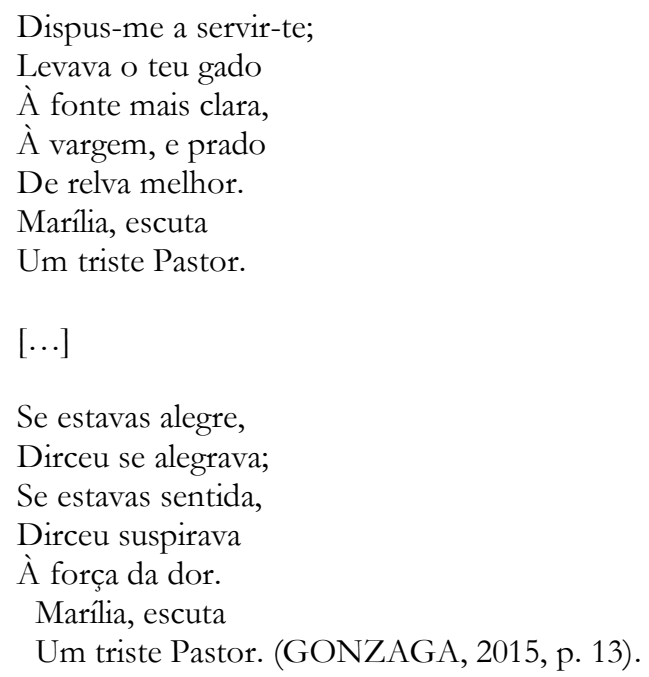

Como se vê, a dor ou a alegria da amada influenciavam o estado de ânimo de Dirceu. Já na lira XI da parte II, o eu lírico busca sua amada à procura de paz. Dirceu encontra nos braços de sua musa o fim de seu sofrimento. Para ele, sair do inferno é encurtar distância entre eles. Com efeito, para o andrógino é inconcebível não procurar sua metade, assim como o eu lírico que, mesmo preso, espera reencontrar seu amor.

Estou no Inferno, estou, Marília bela;

E numa coisa só é mais humana

A minha dura estrela:

Uns não podem mover do Inferno os passos;

Eu pretendo voar, e voar cedo

À glória dos teus braços. (GONZAGA, 2015, p. 100).

É interessante notar que quanto mais Dirceu afasta-se de sua amada, mais demonstra sentir sua falta e a enaltece, como percebido por Almeida, em sua pesquisa. Na segunda parte, o tom é de tristeza e de esperança, de escuridão relativa ao presente e de claridade relativa a um possível futuro feliz, num reencontro com Marília. É como se um andrógino tivesse encontrado sua metade (primeira parte do livro) e, depois, tivesse sido separado dela (segunda parte). Ao encontrar sua metade, engrandece-se, sente-se forte. Ao ser separado dela, percebe que sensação fora produzida pelo ente amado, daí seu enaltecimento.

O quarto discurso é feito pelo médico Erixímaco. Para ele, o amor não pertence somente ao homem, mas ao âmbito mais geral da natureza:

[...] que porém não está ele apenas na alma dos homens, e para com os belos jovens, mas também nas outras partes, e para com muitos objetos, nos corpos de todos os outros animais, 


\section{das Letras}

nas plantas da terra e por assim dizer em todos os nossos seres é o que creio ter constatado pela prática da medicina, a nossa arte. (PLATÃO, O banquete, 186 b).

Na Lira XIX da parte I, o amor representado não é somente o amor entre homem e mulher, mas também o amor que acontece na natureza. Nesse poema, Dirceu apresenta três exemplos de amor: o primeiro é o amor da vaca pelo novilho na maneira que limpa seu filhote, o segundo é o de uma cadela pelo filhote quando suporta que lhe salte e lhe morda e o terceiro é que uma ave demonstra por sua cria, colocando-a entre as asas, dando lhe sustento e proteção. Na sequência da lira, ele fala quão alegre será para a sua esposa ter e amar os filhos. Esse amor representado relaciona-se ao conceito de amor de Erixímaco, que se estende a outros elementos da natureza. $\mathrm{Na}$ lira abaixo, o eu lírico canta o amor presente no reino animal e convida Marília para meditar sobre isso:

Enquanto pasta alegre o manso gado,

Minha bela Marília, nos sentemos

À sombra deste cedro levantado.

Um pouco mais meditemos

$\mathrm{Na}$ regular beleza,

Que em tudo quanto vive nos descobre

A sábia natureza.

Atende como aquela vaca preta

O novilho seu dos mais separa,

E o lambe, enquanto chupa a lisa testa.

Atende mais, ó cara,

Como a ruiva cadela

Suporta que lhe morda o filho o corpo,

E salte em cima dela.

Repara como, cheia de ternura,

Entre as asas ao filho essa ave aquenta,

Como aquela esgravata a terra dura,

E os seu assim sustenta;

Como se encoleriza,

E salta sem receio a todo vulto,

Que junto deles pisa.

Que gosto não terá a esposa amante,

Quando der ao filhinho seu peito brando,

E refletir então no seu semblante!

Quando, Marília, quando

Disser consigo: É esta

De teu querido pai a mesma barba,

A mesma boca a mesma testa.

Que gosto não terá a mãe, que toca,

Quando o tem nos seus braços, c'o dedinho

Nas faces graciosas e na boca

Do inocente filhinho!

Quando, Marília bela,

$\mathrm{O}$ tenro infante já tem risos mudos 


\section{das Letras}

\section{Começa a conhecê-la!}

Que prazer não terão os pais, ao verem

Com as mães um dos filhos abraçados;

Jogar outros na luta, outros correrem

Nos cordeiros montados!

Que estado de ventura!

Que naquilo, que de peso serve,

Inspira Amor doçura. (GONZAGA, 2015, p. 51-52).

Agatão, o anfitrião, é o quinto e afirma que os discursos anteriores elogiavam os bens causados aos homens pelo amor, mas não o próprio. Seu discurso opõem-se ao de Fedro, ao dizer que não é o Amor o mais antigo, mas o mais jovem dos deuses e assim sempre permanece. Além disso, afirma que

Não é com efeito sobre a terra que ele anda, nem sobre cabeças, que não são lá tão moles, mas no que há de mais brando entre os seres é onde ele anda e reside. Nos costumes, nas almas de deuses e de homens ele fez sua morada, e ainda, não indistintamente em todas as almas, mas da que encontre com um costume rude ele se afasta, e na que o tenha delicado ele habita. (PLATÃO, O banquete, 195e).

Para Agatão, o amor mora e anda nas almas dos homens. Entretanto, segundo ele, o amor só habita nas que tenham costumes delicados e afasta-se daquelas que são rudes. Na lira VIII da primeira parte, Dirceu diz a Marília que ninguém está isento ao amor. Para defender sua tese, ele faz analogias com personagens mitológicos e, também, com alguns animais. Contudo o objetivo de sua questão é verificar se Marília pode ou não ser isenta de amar. Segundo Agatão, é possível que sim, mas para Dirceu não.

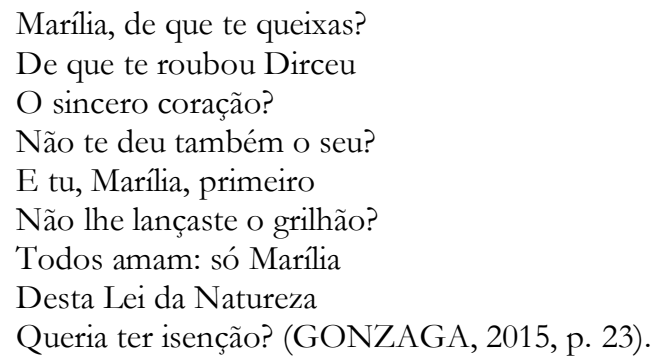

Ou seja, para Dirceu, todos amam, inclusive os animais, o que contraria a afirmativa de Agatão, para quem o amor só reside nas pessoas de costumes delicados, mas aproxima-se do discurso de Eurixímaco.

$\mathrm{Na}$ continuação do discurso, Agatão faz o seu louvor, elogiando e apontando as qualidades do amor. Para ele, o amor deve guiar as relações sociais e ser celebrado pelos homens com belos hinos.

É ele que nos tira o sentimento de estranheza e nos enche de familiaridade, promovendo todas as reuniões deste tipo, para mutuamente nos encontrarmos, tornando-se nosso guia nas festas, nos coros, nos sacrifícios; incutindo brandura e excluindo rudeza; pródigo de bemquerer e incapaz de mal-querer; propício e bom; contemplado pelos sábios e admirado pelos deuses; invejado pelos desafortunados e conquistado pelos afortunados; do luxo, do requinte, 


\title{
das Letras
}

do brilho, das graças, do ardor e da paixão, pai; diligente com o que é mau; no labor, no temor, no ardor da paixão, no teor da expressão, piloto e combatente, protetor e salvador supremo, adorno de todos os deuses e homens, guia belíssimo e excelente, que todo homem deve seguir, celebrando-o em belos hinos, e compartilhando do canto com ele encanta o pensamento de todos os deuses e homens. (PLATÃO, O banquete, 197d-e).

A fascinação de Dirceu pela beleza de sua musa fica ainda mais evidente nos poemas da primeira parte, como é possível destacar na terceira e quarta estrofes da Lira II, em que ele descreve as características do rosto de Marília, usando metáforas e símiles. Dirceu faz a própria Marília ser metáfora de amor. Percebe-se na lira alto grau de idealização da bela. Percebe-se também alto grau de idealização do amor em Agatão. A comparação com personagens consagrados é usada para reforçar a perfeição atribuída ao cabelo de Marília, o contraste entre a pele e o cabelo da moça representam o belo. Depois transforma Marília em codinome amor e diz que seus olhos são sóis, exaltando o fato de serem dois os dela, enquanto no céu haver só um.

Os seus compridos cabelos,

Que sobre as costas ondeiam,

São que os de Apolo mais belos;

Mas de loura cor não são.

Têm a cor da negra noite;

E com o branco do rosto

Fazem, Marília, um composto

Da mais formosa união.

Tem redonda, e lisa testa,

Arqueadas sobrancelhas;

A voz meiga, a vista honesta,

E seus olhos são uns sóis.

Aqui vence Amor ao Céu,

Que no dia luminoso

O Céu tem um Sol formoso,

E o travesso Amor tem dois. (GONZAGA, 2015, p 10).

$\mathrm{Na}$ lira XIX da II parte, o eu lírico faz menção ao bem que o amor lhe causa. Pois estando Dirceu encarcerado na triste masmorra, seu amor por Marília é que lhe ajuda a resistir ao mal de estar preso. Percebe-se aí a relação com o discurso de Agatão, pois o amor é causador do bem ao amado.

\author{
Nesta triste masmorra, \\ De um semivivo corpo sepultura, \\ Inda, Marília, adoro \\ A tua formosura. \\ Amor na minha ideia te retrata; \\ Busca, extremoso, que eu assim resista \\ A dor imensa, que me cerca e mata. (GONZAGA, 2015, p. 114).
}

Dirceu acredita que o amor é capaz de lhe trazer o bem, assim como no discurso de Agatão.

O último discurso é o de Sócrates. Essa parte é a mais complexa e importante, pois em seu discurso entra outro diálogo, que ele tivera com Diótima. Seu discurso começa no parágrafo 199c: 
primeiro ele faz algumas perguntas a Agatão, com o objetivo de argumentar a partir das respostas deste. Depois narra o que aprendeu com Diótima a respeito do tema. Para ele, o amor é a vontade de ter o bem consigo, por isso é algo comum a todos. É o que sempre se busca, porque é algo do qual se tem falta. "[...] o Amor, tu reconheceste que, por carência do que é bom e do que é belo, deseja isso mesmo de que é carente.” (PLATÃO, O banquete, 202d).

E por ser filho o Amor de Recurso e de Pobreza foi esta a condição que ele ficou. Primeiramente é sempre pobre, e longe está de ser delicado e belo, como a maioria imagina, mas é duro, seco, descalço e sem lar, sempre por terra e sem forro, deitando-se ao desabrigo, às portas e nos caminhos, porque tem a natureza da mãe, sempre convivendo com a precisão. Segundo o pai, porém, ele é insidioso com o que é belo e bom, e corajoso, decidido e enérgico, caçador terrível, sempre a tecer maquinações, ávido de sabedoria e cheio de recursos, a filosofar por toda a vida, terrível mago, feiticeiro, sofista; e nem imortal é a sua natureza nem mortal, e no mesmo dia ora ele germina e vive, quando enriquece, assim como também está no meio da sabedoria e da ignorância. (PLATÃO, O banquete, 203d-e).

O amor descrito por Sócrates é o que conclui o ciclo de louvor feito ao amor pelos personagens do banquete. No discurso de Sócrates, Diótima conta que o amor herdou características da mãe, Pobreza, e de seu pai, Recurso, e não é mortal nem imortal. E pela mãe está sempre em desabrigo, às portas e nos caminhos. E pela natureza do pai arma ciladas para o que é belo.

Na lira IX da primeira parte, nota-se que Dirceu caiu na cilada do amor. Para Sócrates, o amor está sempre atrás de pessoas dispostas a servi-lo, eis que o belo seriam os amantes, pois o amor torna belo aquele que ama. $\mathrm{O}$ amor de Dirceu faz com que Marília torne-se sinônimo de amor.

Eu sou, gentil Marília, eu sou cativo;

Porém não me venceu a mão armada

De ferro, e de furor:

Uma alma sobre todas elevada

Não cede a outra força, que não seja

A tenra mão de amor. (GONZAGA, 2015, p. 25)

O amor é representado pelo desejo do amante pela pessoa amada.

[...] Se algum dia o vires, não é como ouro ou como roupa que ele te parecerá ser, ou como os belos jovens adolescentes, a cuja vista ficas agora aturdido e disposto, tu como outros muitos, contanto que vejam seus amados e sempre estejam com eles, a nem comer nem beber, se algum modo fosse possível, mas a só contemplar e estar ao seu lado. (PLATÃO, O banquete, 211d-e).

$\mathrm{Na}$ lira XXI, da primeira parte, Dirceu descreve os efeitos que lhe causou o amor. Tudo começa quando ele viu o rosto de Marília. Nessa lira, o eu lírico entoa o refrão, perguntando se os resultados de suas ações seriam por causa do amor. A pontuação do refrão é decisiva para a conclusão da lira, porque nas quatro primeiras estrofes é empregado o sinal de interrogação, mas na última é empregado o ponto de exclamação, mostrando então a dor do eu lírico pela falta de Marília. Então, como o próprio Dirceu afirma, são os efeitos do amor. No trecho a seguir, percebe-se o medo que ele tem de ficar sem Marília, pois ao sonhar com a morte dela, gela-se o sangue nas veias. 


\section{das Letras}

$[\ldots]$

Se geme o bufo agoureiro,

Só Marília me desvela,

Enche-se o peito de mágoa,

E não sei a causa dela.

Mal durmo, Marília, sonho

Que fero leão medonho

Te devora nos meus braços:

Gela-se o sangue nas veias,

E solto do sono os laços

À força da imensa dor.

Ah! que os efeitos, que sinto,

Só são efeitos de Amor! (GONZAGA, 2015, p. 55).

$\mathrm{Na}$ lira IV da segunda parte, Dirceu busca em Marília a juventude que perdera:

Já, já me vai, Marília, branquejando

Louro cabelo, que circula a testa;

Este mesmo, que alveja, vai caindo E pouco me resta.

\section{$[\cdots]$}

Mal te vir, me dará em poucos dias

A minha mocidade o doce gosto;

Verás burnir-se a pele, o corpo encher-se,

Voltar a cor ao rosto. (GONZAGA, 2015, p. 95-96).

É possíve perceber, nesse poema, que a presença de Marília é o remédio para a velhice do poeta, assim como na lira VI, em que ela é fonte de força e de esperança para o eu lírico, que padece torturas tântricas com a sua ausência:

$[\cdots]$

Não vejo os pomos, nem as águas vejo,

Que de mim se retiram quando busco

Fartar o meu desejo;

Mas quer, Marília, o meu destino ingrato

Que lograr-te não possa, estando vendo

Nesta alma o teu retrato.

Estou no Inferno, estou, Marília bela;

E numa coisa só é mais humana

A minha dura estrela:

Uns não podem mover do Inferno os passos;

Eu pretendo voar, e voar cedo

À glória dos teus braços (GONZAGA, 2015, p.109).

Nessa lira, Dirceu é martirizado por "[...] aflições tiranas, que aos Precitos / Arbitra Radamanto em justa pena / Dos bárbaros delitos" (GONZAGA, 2015, p. 108). Suas entranhas 
não são devoradas por um "abutre esfaimado", mas ele sente "de outro monstro a crueldade: / O abutre da saudade" (GONZAGA, 2015, p. 109). Todos esses tormentos, que igualam seu sofrimento aos de Sísifo, Tântalo e Títio, são filhos da privação à qual está sujeita o amor e que lhe faz buscar arduamente pela pessoa amada. Estando Dirceu preso, numa masmorra imunda, como declara em mais de uma lira, Marília bela é mais ardentemente desejada por representar a beleza e a liberdade e sua ausência transforma-se em suplício e em tirana saudade.

Os discursos de Fedro, Pausânias, Aristófanes, Erixímaco e Agatão tentam, cada um à sua maneira, argumentar em favor de uma ideia sobre o amor. Entretanto, Sócrates com sua tese derruba os argumentos de seus companheiros. Para ele, o amor é representado pelo desejo, ou seja, pela falta. Sendo assim, o amor não torna virtuoso aquele que ama, como afirma Fedro, mas faz aquele que ama buscar o virtuoso; ele não é jovem nem vive na alma dos delicados, mas faz aquele que ama buscar a juventude e a delicadeza, assim como Dirceu buscava em Marília a graça e a juventude. Como o amor vive de carência, é essa carência que o faz buscar, como um andrógino, o recurso, ou seja, o belo para fartar-se por toda a vida, o que ele não consegue, já que a falta é uma de suas características.

$\mathrm{Na}$ obra analisada, o desejo também nunca se consome, sempre tem algo que o eu lírico quer da musa. E quanto maior a falta, mais intenso é o amor. Com efeito, inicialmente parecia que era o amor em si belo, por isso Agatão foi aclamado. No entanto, na lógica de Sócrates belo não é o amor, mas sim o que ele deseja. Percebe-se aí a relação com o discurso de Sócrates, na primeira parte e, principalmente, na segunda parte do livro. Devido ao fato de Dirceu encontrar-se preso, a falta de Marília aumenta, aumentando seu desejo por ela, que representa a liberdade, ou melhor, representa o bem e o belo, ou seja, o amor. Só quem ama sente saudades.

Mas ainda há o último discurso, que é o de Alcibíades. Ele vem reforçar a importância do discurso de Sócrates. Chega ao banquete bêbado e, por nessa condição encontrar-se, preferiu não louvar o amor. Entretanto propõe-se a discursar a respeito de Sócrates. Alcibíades mostra-se desejoso e pronto para armar ciladas para Sócrates. Entretanto, como a questão proposta no artigo concretiza-se com o discurso de Sócrates, não se aprofundou no discurso de Alcibíades. ${ }^{1}$

\section{CONCLUSÃO}

Cada discurso do livro O banquete (1972) de Platão contribuiu à sua maneira para esta pesquisa. Fedro ajudou com a definição de que o amor seria um deus, o mais antigo, e que torna virtuoso quem ama. Pausânias mostrou dois tipos de amor: um ligado a mente, Urânio, e outro ligado ao corpo, Pandêmio. Aristófanes com o mito dos Andróginos mostra a busca do amado pelo amante. Para Erixímaco, o médico, o amor é uma força natural que harmoniza as coisas opostas. Agatão define o que é belo, levando a se entender que belo é o próprio amor. E Sócrates diz que o amor não é nada disso que os outros afirmaram, mas, sim, é carente de todas essas características que os demais convivas do banquete lhe deram, por isso as busca no amado.

Levando isso em consideração, após a análise, percebeu-se que o amor nas duas primeiras partes de Marília de Dirceu é representado pela falta que o eu lírico sente de sua amada. O homem deseja ser feliz, e os bens que a companhia dela lhe causa proporcionam o desejo de tê-la consigo. Isso é acentuado na segunda parte da obra, já que, como Dirceu se encontra preso, Marília passa

\footnotetext{
${ }^{1}$ Seguiu-se a maioria dos comentadores, segundo os quais "sob a influência de Robin, Alcibíades é o descrente com relação à possibilidade de os discursos não-filosóficos terem constituído oposições, seja do ponto-de-vista do conteúdo ou da forma, de fato consistentes à formulação socrática do amor". (FRANCO, 2008, p. 61).
} 
a representar tudo que é bom (liberdade) e tudo que é belo, acentuando a procura e a vontade de reencontrá-la. Na primeira parte do livro, Marília também significa o que falta a Dirceu: a juventude. Por mais que ele tente, como demonstrado por Almeida (2006), exaltar-se por causa de sua experiência de vida e de seus conhecimentos, nada disso é capaz de substituir a juventude, que a amada possui e representa. Ao enaltecer-se por suas qualidades (experiência e conhecimento), Dirceu tenta compensar o que lhe falta e o que procura em Marília: juventude e depois liberdade.

O amor, em Marília de Dirceu, assim como para Sócrates, não é divino, nem humano, mas aquilo que faz a ponte entre o humano e o divino, aquilo que permitiria a Dirceu encontrar um estado de beatitude. Daí a constante busca do pastor-poeta. Se as liras, analisadas individualmente, apresentam uma ou outra, em uma primeira leitura, uma das definições do amor presente nos demais discursos de O Banquete; a primeira e a segunda partes de Marília de Dirceu mostram, em conjunto, o amor socrático que, sendo filho de Recurso e de Pobreza, é a materialização da busca (pobreza) pelo belo e pelo bom (recurso). Dessa maneira, percebe-se que Dirceu busca em Marília aquilo que lhe falta, por isso ama, não Marília em si, mas aquilo que ela representa: beleza, graça, juventude e liberdade.

\section{REFERÊNCIAS}

ALMEIDA, Pedro. Marília de Dirceu e Dirceu de Marília: uma proposta de leitura das liras de Tomás Antônio Gonzaga. Revista da Faculdade de Letras - Línguas e Literaturas, II Série, vol. XXIII, Porto, 2006 [2008], p. 179-220. Disponível em: <http://ler.letras.up.pt/uploads/ficheiros/5643.pdf>. Acesso em: 01 set. 2016. BOSI, Alfredo. História concisa da literatura brasileira. 43 ed. São Paulo: Cultrix, 2006.

CANDIDO, Antônio. Formação da literatura brasileira: momentos decisivos. 12. ed. Rio de Janeiro: Ouro sobre azul, 2010.

CANDIDO, Antônio. Na sala de aula: caderno de análise literária. 8. ed. São Paulo: Ática, 2009. COUTINHO, Afrânio. A literatura no Brasil. 7. ed. São Paulo: Global, 2004.

FRANCO, Irley F. Uma hipótese sobre o Banquete de Platão. Ethica. Rio de Janeiro, v. 15, p. 59-74, 2008. Disponível em:

$<$ https://www.academia.edu/5060467/Uma_Hip\%C3\%B3tese_sobre_o_Banquete_de_Plat\% C3\%A3o >. Acesso em: 10 nov. 2016.

GIL, Antônio Carlos. Como elaborar projeto de pesquisa. 4.ed. São Paulo: Atlas, 2009.

GONZAGA, Tomás Antônio. Marília de Dirceu. Porto Alegre: L\&PM, 2015.

PLATÃO. O Banquete. São Paulo: Abril, 1972.

OLIVEIRA, Ilca Vieira. Gonzaga, tradição, recepção e reescrita. Revista do programa de pósgraduação em Letras. Santa Maria, n. 22, p. 97-105, jun. 2001. Disponível em:< https://periodicos.ufsm.br/letras/article/view

Recebido em: 05/05/2018

Aprovado em: 20/09/2018

Publicado em: 01/12/2018 